\title{
EFFECT OF IRRIGATION INTERVALS AND BIOFERTILIZATION ON GROWTH, YIELD, OIL PRODUCTION AND CHEMICAL CONSTITUENTS OF ROSEMARY ( Rosmarinus officinalis,L.) PLANTS.
}

\author{
A. S. El-Leithy* ; Salem, M. A. *; El-Ghadban, E. A. ** and Abd El-Ghani, N.M. ** \\ * Ornamental Hort. Department, Fac. Agric., Cairo Univ., Egypt. \\ **Med. and Arom. Plant Research Dept., Hort. Research Instit., Agric. Research \\ Center, Dokki, Giza, Egypt.
}

\section{ABSTRACT}

This investigation was carried out aiming to study the effect of irrigation intervals (every 7,11 and 15 days) and Biofertilization (nitrobien and phosphorein each at 0,3 and $6 \mathrm{~g} / \mathrm{pot}$ ) on growth, yield, oil production and chemical composition of rosemary (Rosmarinus officinalis, L.), during two successive seasons of 2004 and 2005.

The results showed that irrigation every 7 days gave the tallest plant, the highest oil percentage and oil yield/ plant in the first cut of both two seasons, the highest number of branches/ plant, fresh and dry weights/plant, total carbohydrates, $N, P$ and $K$ percentage in the first and second cut of both seasons and gave the highest linalool and P-cymene percentages in the essential oil. Whereas irrigation every 11 days gave the tallest plant, the highest oil percentage and oil yield/ plant in the second cut of both seasons and the highest $\alpha$-pinene, $\beta$-pinene, limonene, 1,8 cineol and camphor percentages compared to irrigation every 15 days which gave the lowest values.

Nitrobien and phosphorein at 3 and $6 \mathrm{gm} /$ pot significantly increased plant height, number of branches/ plant, fresh and dry weights/ plant and oil yield/ plant, and increased the main constituents of the essential oil $(\gamma$ Terpenene, 1,8 cineol, linalool, camphor, P-cymene, bornyl acetate and $\beta$ caryophyllene percentages ), total carbohydrates, $N, P$ and $K$ contents in the first and second cut of both two seasons compared to unfertilized control.

Interaction between irrigation intervals and bio-fertilization had a significant effect on vegetative growth characteristics and oil percentage and oil yield. Irrigation every 7 days and phosphorein at $6 \mathrm{~g} / \mathrm{pot}$ gave the highest values of plant height (in the first cut), number of branches /plant ( second cut), fresh and dry weights /plant (in the first cut, oil yield /plant (in the first cut), total carbohydrates, $N$ and $P$ contents in the first and second cut of both seasons. Whereas irrigation every 11 days and phosphorein application at $6 \mathrm{~g}$ /pot gave the highest dry weight/ plant, oil percentage and oil yield/ plant in the second cut of both two seasons. irrigation every 11 days and nitrobien application at $3 \mathrm{~g} /$ pot gave the highest $\beta$-pinene, 1,8 cineol, camphor and bornyl acetate percentages in the essential oil. Whereas irrigation every 11 
days and phosphorein at $3 \mathrm{gm} /$ pot gave the highest linalool and P-cymene percentages in the essential oil.

Keywords: Irrigation intervals, biofertilization, growth, yield, oil production, chemical constituents, rosemary (rosmarinus officinalis,1.) plants.

\section{INTRODUCTION}

Rosemary (Rosmarinus officinalis, L.) belongs to family Lamiaceae (Labiatae) is a shrubby evergreen bush up to 2 meters high with silvery- green, needle shaped leaves and pale blue flowers. The whole plant is strongly aromatic. It is one of the earliest plants to be used for food and medicine. It has been used for a wide range of complaints including respiratory and circulatory disorders, liver congestion, digestive and nervous complaints, muscular and rheumatic pain, skin and hair problems (Lawless, 1992).

The effect of irrigation treatments on growth and yield of many aromatic and medicinal plants were studied by several researchers; Yassen et al. (2003) on Ocimum basilicum; Aly (2004) on Senna occidentalis and Singh (2004) on rosemary.

The effect of bio-fertilizers on growth and yield of many aromatic and medicinal plants were studied by several researchers; Salman (2004) on basil; Youssef et al. (2004) on sage; Zayed et al. (2004) on borage ; Migahed et al. (2004) celery; Shalan (2005) on borage; Heikal (2005) on thyme and Sakr (2005) on senna plants.

\section{MATERIALS AND METHODS}

This investigation was carried out at the Experimental Farm of Ornamental Horticulture Department, Faculty of Agriculture, Cairo University and Medicinal and Aromatic Plant Research Department, Horticulture Research Institute, Agricultural Research Center, Dokki, Giza, in two successive seasons of 2004 and 2005. The aim of this study was to investigate the effect of irrigation intervals and Bio-fertilization on growth, yield, oil production and chemical composition of rosemary (Rosmarinus officinalis, L.).

Rooted cuttings (15-20 cm long) of Rosmarinus officinalis, L. plants were planted on $28^{\text {th }}$ February in the two seasons of 2004 and 2005 into $30 \mathrm{~cm}$ (diameter) clay pots filled with sandy loam soil. Physical and chemical characters of the soil are shown in Table (A).

Bio-fertilizers ( nitrobien and phosphorein) were inserted in the soil surface at the rates of 0,3 and $6 \mathrm{~g} /$ pot when the rooted cuttings were transplanted.

The experiment included 3 irrigation intervals every 7, 11 and 15 days after two weeks from transplanting. 
Table A: Chemical and physical properties of the experimental soil.

\begin{tabular}{|c|c|c|c|c|c|c|c|c|c|c|c|c|}
\hline \multicolumn{13}{|c|}{ Physical properties } \\
\hline \multicolumn{2}{|c|}{ Sample } & \multicolumn{4}{|c|}{ Sand $\%$} & \multicolumn{3}{|c|}{ Clay $\%$} & \multicolumn{4}{|c|}{ Silt \% } \\
\hline \multicolumn{2}{|c|}{ Sandy loam } & \multicolumn{3}{|c|}{55.2} & & \multicolumn{3}{|c|}{18.5} & \multicolumn{4}{|c|}{26.3} \\
\hline \multicolumn{13}{|c|}{ Chemical properties } \\
\hline \multirow[b]{2}{*}{ pH } & \multirow{2}{*}{$\begin{array}{l}\mathrm{EC} \\
\mathrm{mmhos} \\
\mathrm{cm} / \mathbf{2 5}^{\circ} \\
\mathrm{C}\end{array}$} & \multicolumn{8}{|c|}{ Soluble cations and anions (meq/L) } & \multicolumn{3}{|c|}{$\begin{array}{l}\text { Available } \\
\text { (ppm) }\end{array}$} \\
\hline & & '́n & $\overbrace{0}^{1}$ & 已 & ¿ & $\pm_{\pi}^{+}$ & $\sum_{\infty}^{+\infty}$ & ${ }^{+}$ & \pm & $\mathbf{N}$ & $\mathbf{P}$ & $\mathbf{K}$ \\
\hline 7.5 & 4.45 & -- & 2.0 & 7.14 & 33.48 & 18.76 & 14.4 & 12.7 & 6.76 & 24. & 208 & 340.7 \\
\hline
\end{tabular}

The experimental layout was factorial experiment design. The main plots were irrigation intervals and the sub- plots were bio-fertilizer treatments, including 15 treatments. Each treatment was replicated 3 times and each replicate consisted of 6 plants.

The plants were harvested twice /season (first and second cuts) on August $9^{\text {th }}$ and November $15^{\text {th }}$ in both seasons, by cutting the herb of the plants at $10 \mathrm{~cm}$ above the soil surface.

The following data were recorded in the first and second cuts, in both seasons. Plant height, number of branches /plant, plant fresh weight (g), plant dry weight (g), essential oil percentage in fresh herb, oil yield of fresh herb/plant. Essential oil percentage in the fresh herb was determined according to the British Pharmacopoeia (1963). Gas Liquid Chromatography (GLC) analysis of the essential oil in the first cut of the first season was performed using Ds- Chrom. 6200 Gas Chromatography equipped with flame ionization detector (FID) under the conditions of : Column with a coating film of $3 \%$ OV-17 ( Methyl phenyl Silicone ) on chromosorb - WHP.(1.5 X $4.0 \mathrm{~mm}$ and $100-120 \mathrm{mesh}$ ), and injector temperature of $250^{\circ} \mathrm{C}$. Nitrogen flow rate at $30 \mathrm{ml} / \mathrm{min}$, hydrogen flow rate at $30 \mathrm{ml} / \mathrm{min}$ and air flow rate at $330 \mathrm{ml} / \mathrm{min}$ with an initial temperature of $70^{\circ} \mathrm{C}-$ P.R. $8^{\circ} \mathrm{C}$ and final temperature of $200^{\circ} \mathrm{C}$, chart speed was $2 \mathrm{~min} . / \mathrm{cm}$., Range 32 as described by Bunzen et al. (1969). The following chemical composition were determined in the dry matter of the plants in both cuts of the first and second seasons ; Total carbohydrates contents were determined using the method described by (Herbert et al.,1971). Nitrogen percentage determined according to Koch and Mc-Meeking (1924). Phosphorus percentage determined as recommended by King (1951). Potassium percentage determined using atomic absorption spectrophotometer (Perkin Elemer, Model 3300).

Data recorded on growth parameters, volatile oil percentage and oil yield/ plant were statistically analyzed, and separation of means was performed using the 
Least Significant Difference (L.S.D.) test at the 5\% level, as described by Snedecor and Cochran (1980).

\section{RESULTS AND DISCUSSION}

\section{Plant height (cm):}

Data presented in Table 1 showed that irrigation intervals had a significant effect on plant height in both seasons. In the first cut, in the first season, irrigation every 7 days was the most effective treatment, which gave the tallest plant followed by irrigation every 11 days compared with for plants irrigated every 15 days. In the second cut the highest value was obtained from plants irrigated every 15 days compared to plants irrigated every 11 days. In the second season, first cut, similar results were obtained as in the first one, i.e., prolonging irrigation intervals gradually decreased plant height. Irrigation every 7 days was the most effective treatment, which gave the tallest plants compared to for plants irrigated every 15 days, while in the second cut the highest value was obtained from plants irrigated every 15 days compared to for plants irrigated every 7 days.

Generally, it could be concluded that irrigation at short interval increased plant height especially in the first cut of both seasons. These results are in agreement with those obtained by Hammoda (2001) on moghat and Hammam (2002) on Cassia acutifolia. They showed that prolonging irrigation intervals decreased plant height.

Regarding the effect of bio-fertilization, both nitrobien and phosphorein at the rates of 3 and $6 \mathrm{~g}$ /pot significantly increased plant height in both two cuts of both seasons. In the first cut of both first and second seasons the highest values were obtained from plants fertilized with phosphorein and nitrobien at $3 \mathrm{~g} /$ pot, respectively compared to un fertilized plants. In the second cut of both first and second seasons, the highest values were produced from plants fertilized with phosphorein at the highest rate $6 \mathrm{~g} / \mathrm{pot})$ compared to for control plants. These results are in harmony with the findings obtained by. Mahfoz (2003) on marjoram plant, showed that application of bio-fertilizers increased plant height. Shalan (2005) on borage plants, reported that bio-fertilizers application increased plant height.

Interaction between irrigation intervals and bio-fertilizers had a significant effect on plant height in both seasons. In the first cut of the first season, plants treated with nitrobien at $3 \mathrm{~g} / \operatorname{pot}\left(\mathrm{N}_{1}\right)$ or phosphorein at $6 \mathrm{~g} / \operatorname{pot}\left(\mathrm{P}_{2}\right)$ plus irrigation every 7 days gave the tallest plants compared with control plants( without bio-fertilizer) and irrigated every 15 days which gave the shortest plants. In the second cut of the first season the tallest plants were obtained from irrigation every 15 days with phosphorein at $6 \mathrm{~g}$ /pot compared to the lowest value for plants treated with irrigation intervals every 11 days with phosphorein at $6 \mathrm{gm} /$ pot. In the second season, in first cut, the treatment of irrigation intervals every 7 days and fertilized with nitrobien at 3 $\mathrm{g} /$ pot gave the tallest plants compared to for control plants( without bio-fertilizer) and irrigation every 15 days. In the second cut the highest value was obtained from 
Table 1 : Effect of irrigation intervals and bio-fertilizers on plant height $(\mathrm{cm})$ of rosemary (Rosmarinus officinalis, L.) plants during 2004 and 2005 seasons.

\begin{tabular}{|c|c|c|c|c|c|c|c|c|}
\hline \multirow{2}{*}{$\begin{array}{l}\begin{array}{r}\text { Irrigation } \\
\text { Intervals }\end{array} \\
\text { Bio- } \\
\text { fertilizers }\end{array}$} & 7days & 11days & 5 days & Mean & 7days & 11days & 15days & Mean \\
\hline & \multicolumn{4}{|c|}{ First cut } & \multicolumn{4}{|c|}{ Second cut } \\
\hline & \multicolumn{8}{|c|}{2004} \\
\hline Control & 19.17 & 13.44 & 12.50 & 15.04 & 13.22 & 11.33 & 11.50 & 12.02 \\
\hline N1 & 21.67 & 18.39 & 17.00 & 19.02 & 13.17 & 14.17 & 14.50 & 13.94 \\
\hline $\mathbf{N 2}$ & 19.33 & 18.33 & 16.00 & 17.89 & 11.83 & 13.67 & 12.67 & 12.72 \\
\hline P1 & 21.33 & 20.17 & 17.67 & 19.72 & 15.33 & 12.50 & 11.67 & 13.17 \\
\hline $\mathbf{P 2}$ & 21.67 & 20.17 & 15.67 & 19.17 & 14.00 & 10.33 & 18.33 & 14.22 \\
\hline Means & 20.63 & 18.10 & 15.77 & & 13.51 & 12.40 & 13.73 & \\
\hline \multicolumn{9}{|c|}{ L.S.D. at 0.05 for : } \\
\hline Irrigation (A) & & & & 0.80 & & & & 1.32 \\
\hline Bio-fertilizer & & & & 1.04 & & & & 1.70 \\
\hline \multirow[t]{2}{*}{ A $\times$ B } & & & & 1.79 & & & & 2.94 \\
\hline & \multicolumn{8}{|c|}{2005} \\
\hline Control & 20.50 & 16.33 & 16.17 & 17.67 & 14.44 & 13.00 & 12.33 & 13.26 \\
\hline N1 & 25.50 & 21.89 & 20.33 & 22.57 & 14.67 & 16.17 & 17.50 & 16.11 \\
\hline N2 & 21.00 & 19.22 & 20.33 & 20.18 & 13.50 & 17.50 & 17.17 & 16.06 \\
\hline P1 & 23.83 & 20.44 & 20.50 & 21.59 & 17.33 & 16.00 & 14.83 & 16.06 \\
\hline $\mathbf{P 2}$ & 23.83 & 22.84 & 19.83 & 22.17 & 14.50 & 14.33 & 20.17 & 16.33 \\
\hline Means & 22.93 & 20.15 & 19.43 & & 14.89 & 15.40 & 16.40 & \\
\hline \multicolumn{9}{|c|}{ L.S.D. at 0.05 for : } \\
\hline Irrigation (A) & & & & 0.77 & & & & 0.77 \\
\hline Bio-fertilizer & & & & 0.99 & & & & 1.00 \\
\hline A $\times$ B & & & & 1.72 & & & & 1.73 \\
\hline $\begin{array}{l}\mathrm{N} 1=\text { Nitrobien } \\
\mathrm{N} 2=\text { Nitrobien }\end{array}$ & $\begin{array}{l}3 \mathrm{~g} / \mathrm{pot} \\
\text { t } 6 \mathrm{~g} / \mathrm{po}\end{array}$ & & $\begin{array}{l}\mathrm{P} 1= \\
\mathrm{P} 2=\end{array}$ & $\begin{array}{l}\text { sphol } \\
\text { spho }\end{array}$ & $\begin{array}{l}3 \mathrm{~g} / \mathrm{pc} \\
6 \mathrm{~g} / \mathrm{pc}\end{array}$ & & & \\
\hline
\end{tabular}

plants irrigated every 15 days and fertilized with phosphorein at $6 \mathrm{~g} /$ pot. While the lowest value was produced from control plants and irrigated every 15 days.

\section{Number of branches per plant:}

The results in Table 2 indicate that irrigation intervals had a significant effect on number of branches/ plant in both two seasons. In general prolonging irrigation intervals significantly decreased the number of branches per plant. The highest number of branches per plant in the first and second cuts of both first and second seasons were obtained from plants irrigated at the shortest irrigation interval ( 7 days) 
Table( 2 ): Effect of irrigation intervals and bio-fertilizers on number of branches of rosemary (Rosmarinus officinalis, L.) plants during 2004 and 2005 seasons

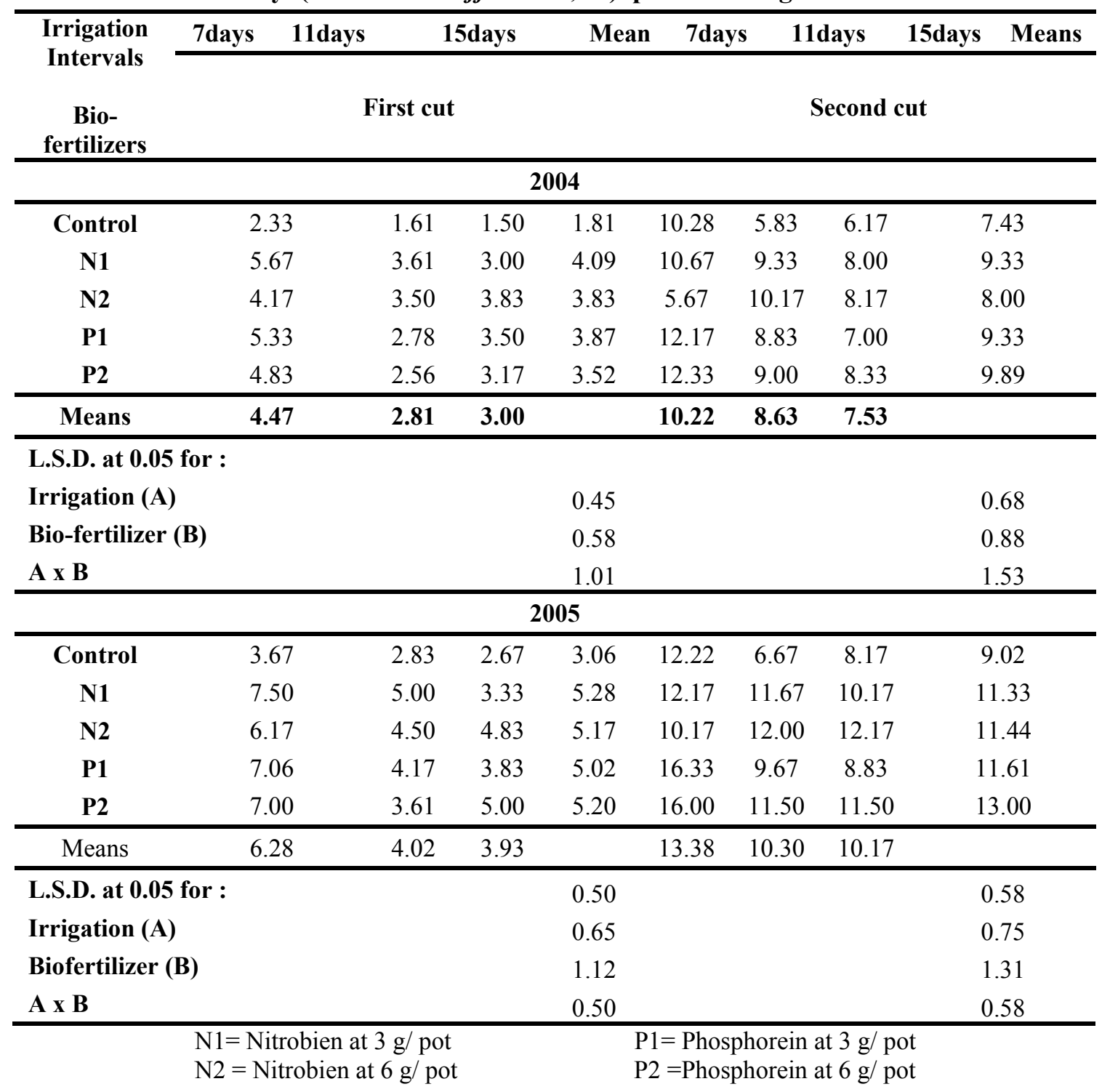

compared to irrigation every 15 days which gave the lowest values. These results are in agreement with those obtained by Hammam (2002) on Cassia acutifolia. They showed that irrigation intervals at long time decreased number of branches/ plant.

Regarding the effect of bio-fertilizers, both nitrobien and phosphorein at 3 and $6 \mathrm{~g} /$ pot significantly increased number of branched /plant in both two seasons. In the first cut, in first and second seasons, nitrobien at $3 \mathrm{gm} /$ pot gave the highest values of number of branches per plant compared to control treatment. Whereas in the second cut in both first and second seasons, phosphorein at $6 \mathrm{gm} /$ pot gave the highest values of number of branches per plant compared to unfertilized control, which gave the 
lowest values. Heikal (2005) on thyme and Sakr (2005) on senna plants. They showed that bio-fertilization treatments increased number of branches /plant.

Concerning the effect of interaction on branching, the data in Table 2 showed a significant effect for the interaction between irrigation intervals and bio-fertilization treatments. Irrigation intervals at 7 days and bio-fertilization with nitrobien at $3 \mathrm{~g} / \mathrm{pot}$ $\left(\mathrm{N}_{1}\right)$ gave the highest number of branches per plant in the first cut of the first and second seasons compared to control plants( without bio-fertilizer) and irrigated every 15 days. Whereas in the second cut of the first season, the highest value of number of branches per plant was obtained from plants irrigated every 7 days and fertilized with phosphorein at $6 \mathrm{~g} /$ pot $\left(\mathrm{P}_{2}\right)$ compared to plants irrigated every 7 days and fertilized with nitrobien at $6 \mathrm{~g} /$ pot. In the second cut, in second season plants irrigated every 7 days and fertilized with phosphorein at 3 and $6 \mathrm{~g}$ /pot gave the highest number of branches per plant compared to control plants irrigated every 11 days .

\section{Fresh weight (g) per plant:}

The data in Table 3 show that irrigation intervals treatments had a significant effect on the fresh weight/ plant. The shortest irrigation interval ( 7 days) gave the highest fresh weight of herb in the first and second cuts in both first and second seasons. Whereas the lowest values were obtained from plants irrigated every 15 days. Prolonging irrigation intervals gradually decreased fresh weight / plant in the two cuts of both two seasons. The differences between 11 and 15 days were statistically significant in the first cut of both two seasons only. These results are in agreement with the findings obtained by Toima et al.(1984) on caraway, Hammoda (2001) on moghat and Hammam (2002) on Cassia acutifolia. They found that short irrigation intervals increased plant fresh weight.

Regarding the effect of bio-fertilization on the fresh weight of rosemary plants, the data in Table 3 show that both nitrobien and phosphorein at 3 or $6 \mathrm{~g} / \mathrm{pot}$ significantly increased herb fresh weight in both two seasons. Nitrobien at $3 \mathrm{~g} / \mathrm{pot}$ $\left(\mathrm{N}_{1}\right)$ gave the highest fresh weight of herb in the first cut of both first and second seasons. While in the second cut of the first and second seasons, phosphorein at $6 \mathrm{~g}$ /pot $\left(\mathrm{P}_{2}\right)$ gave the highest fresh weight of herb per plant compared to control (unfertilized plants) in both two cuts of the two seasons. Similar results were obtained by Heikal (2005) on thyme plant and Sakr (2005) on senna plants. They showed that bio-fertilization treatments increased plant fresh weight.

Interaction between irrigation intervals and bio-fertilizers had a significant effect on fresh weight of herb. Irrigation interval every 7 days and bio-fertilization with phosphorein at $6 \mathrm{gm} /$ pot gave the highest fresh weight of herb per plant in the first cut of both first and second seasons. While in the second cut of the first season, the highest fresh weight of herb per plant was obtained from plants irrigated every 15 days and fertilized with phosphorein at $6 \mathrm{~g} /$ pot. In the second cut of the second season, irrigation intervals at 7 days and phosphorein application at $6 \mathrm{~g} /$ pot gave the highest values of fresh weight of herb per plant, compared to control plants and irrigation every 15 days which gave the lowest values in the first and second cuts of the two seasons. 
Table 3 :Effect of irrigation intervals and bio-fertilizers on fresh weight (g)/ plant of rosemary (Rosmarinus officinalis, L.) plants during 2004 and 2005 seasons.

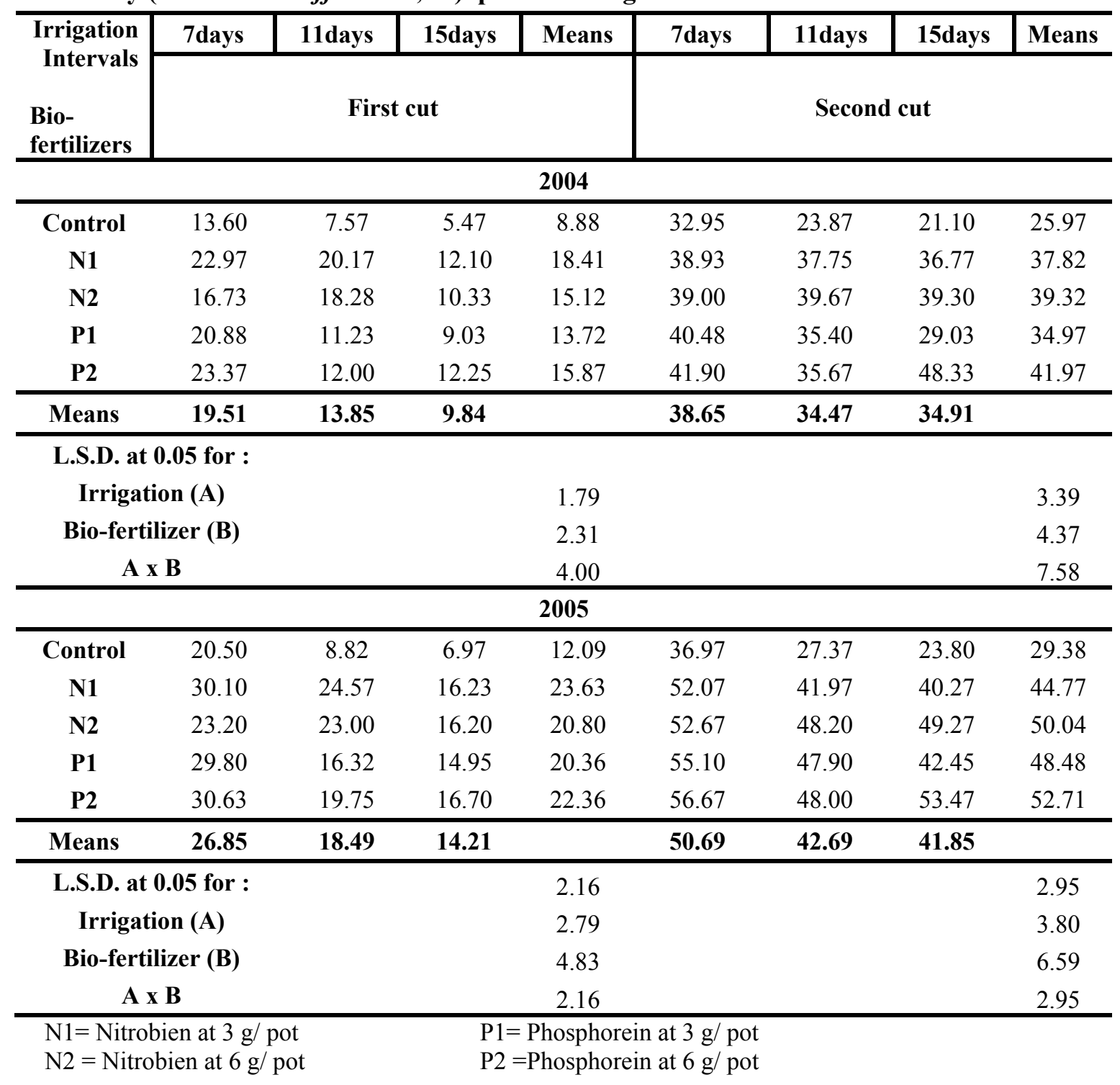

Dry weight (g) per plant:

The data in Table 4 show that in the first cut, in first and second seasons, the shortest irrigation intervals 7 days gave the highest values of dry weight of herb per plant, while in the second cut, in the first season, irrigation every 11 days gave the highest value of dry weight per plant. In the second cut of the second season, the highest value was obtained from plants irrigated every 7 days compared to plants irrigated every 15 days in the first and second cuts of both seasons. These results agree with those obtained by Hammoda (2001) on moghat and Hammam (2002) on senna plants. They found that short irrigation intervals increased plant dry weight. 
Table 4 :Effect of irrigation intervals and bio-fertilizers on dry weight (g)/ plant of rosemary (Rosmarinus officinalis, L.) plants during 2004 and 2005 seasons.

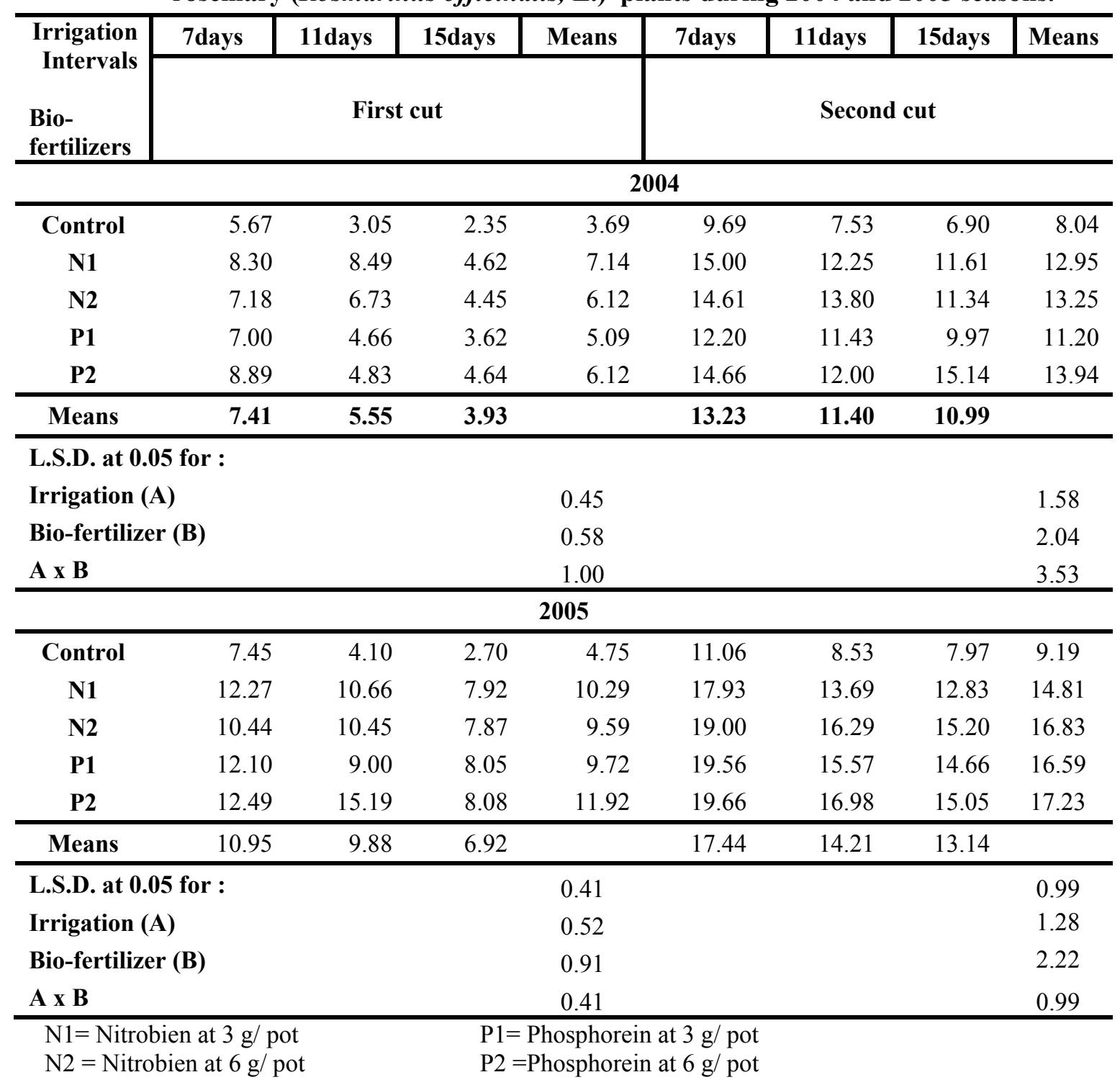

Regarding the effect of bio-fertilization the data in Table 4 show that most of bio-fertilization treatments significantly increased the dry weight of herb compared to the control in the first and second cuts of the first and second seasons. In the first cut of the first season, nitrobien fertilization at $3 \mathrm{~g} /$ pot (N1) gave the highest value of dry weight per plant, while in the second cut, the highest level of Nitrobein $\left(\mathrm{N}_{2}\right)$ gave the highest dry weight/ plant. In the second season, the highest values of dry weight/plant were obtained from plants fertilized with phosphorein at $6 \mathrm{~g} /$ pot $\left(\mathrm{P}_{2}\right)$ in the first and second cuts. Similar results were obtained by Shalan et. al., (2001) on chamomile; Heikal (2005) on thyme plant and Sakr (2005) on senna plants. They showed that biofertilization treatments increased plant dry weight. 
In the first cut of the first season, irrigation every 7 days and fertilization with phosphorein at $6 \mathrm{~g} /$ pot $\left(\mathrm{P}_{2}\right)$ gave the highest value of dry weight, while in the second cut of the first season the highest value was produced from plants irrigated every 15 days and fertilized with phosphorein at $6 \mathrm{~g}$ /pot (P2). In the first cut of the second season, irrigation every 11 days and fertilization with phosphorein at $6 \mathrm{~g}$ /pot (P2) gave the highest value of dry weight of herb, while in the second cut of the second season, the highest value was obtained from plants irrigated every 7 days and fertilized with phosphorein at $6 \mathrm{~g} / \operatorname{pot}(\mathrm{P} 2)$, compared to plants irrigated every 15 days and unfertilized in the first and second cuts in first and second seasons.

\section{Essential oil percentage in fresh herb:}

The oil percentage in fresh herb as affected by irrigation intervals and biofertilization are shown in Table 5.Irrigation intervals had a significant effect on oil percentage in both two seasons. In first cut of the first season, irrigation every 7 days gave the highest value of oil percentage in fresh herb compared to plants irrigated every 15 days, while in the second cut of the first season, the highest value of oil percentage was obtained from plants irrigated every 11 days compared to plants irrigated every 7 days. In the first cut of the second season, the treatment of irrigation interval every 7 days gave the highest value compared to plants irrigated every 11 days, while in the second cut of the second season, the highest value was obtained from plants irrigated every 11 days compared to plants irrigated every 15 days. Also, Yassen et al. (2003) on Ocimum basilicum and Singh (2004) on rosemary. They found that irrigation at short intervals increased essential oil percentage.

Regarding the effect of bio-fertilization, the treatment of nitrobien at $6 \mathrm{~g} / \mathrm{pot}$ ( N2) gave the highest essential oil percentages in the first and second cuts of the first and second seasons compared control plants. Phosphorein at 3 and $6 \mathrm{gm} / \mathrm{pot}$ significantly decreased essential oil percentages in the first cut of both two seasons, while significantly increased it in the second cut of both two seasons as compared with the control plants. These results are confirmed with those obtained by Migahed et al. (2004) on celery; Salman (2004) on basil and Heikal (2005) on thyme plants. They showed that bio-fertilization treatments increased essential oil contents.

Interaction between irrigation intervals and bio-fertilization had a significant effect on oil percentage in both two seasons. In the first cut of the first and second seasons the treatment of irrigation every 7days and nitrobien at $6 \mathrm{~g} /$ pot (N2) gave the highest values of oil percentage. While in the second cut of the first and second seasons, the highest oil percentages in fresh herb were produced from plants irrigated every 11 days and fertilized with phosphorein at $6 \mathrm{gm} /$ pot $(\mathrm{P} 2)$ compared to unfertilized plants and irrigated every 15 days which gave the lowest essential oil percentage.

\section{Essential oil yield (ml/plant):}

The oil yield of fresh herb as affected by irrigation intervals and biofertilization are shown in Table 6. In the first cut of the first and second seasons, irrigation every 7 days significantly increased oil yield/ plant, which gave the highest 
Table 5 :Effect of irrigation intervals and bio-fertilizers on oil percentage(\%) in fresh herb of rosemary (Rosmarinus officinalis, L.) plants during 2004 and 2005.

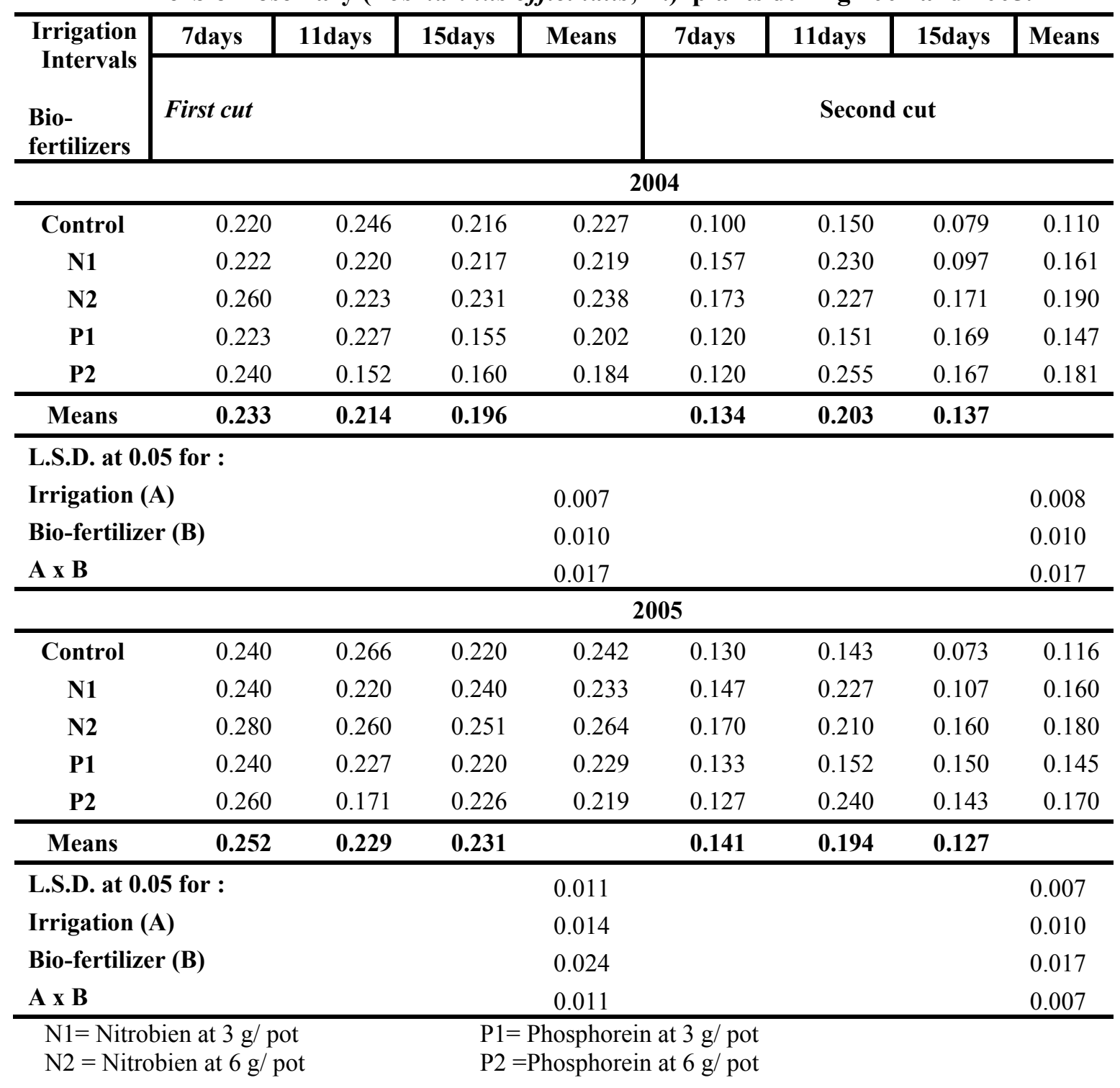

oil yield of fresh herb/ plant compared to plants irrigated every 15 days. While in the second cut of the first and second seasons, the highest values of oil yield of fresh herb/ plant were obtained from plants irrigated every 11 days compared to plants irrigated every 15 days. The differences between irrigation every 7 days and other irrigation intervals were statistically significant in both seasons. The increment in the essential oil yield/ plant may be due to the effect of irrigation at short intervals on increasing both herbage yield and essential oil percentage. Similar results were obtained by, Yassen et. al., (2003) on Ocimum basilicum and Singh (2004) on rosemary. They found that irrigation at short intervals increased essential oil yield. 
Table 6 :Effect of irrigation intervals and biofertilizers on oil yield of fresh herb ( $\mathrm{ml} / \mathrm{plant})$ of rosemary (Rosmarinus officinalis, L.) plants during 2004 and 2005 seasons.

\begin{tabular}{|c|c|c|c|c|c|c|c|c|}
\hline Irrigation & 7days & 11days & 15days & Means & 7days & 11days & 15days & Means \\
\hline & \multicolumn{4}{|c|}{ First cut } & \multicolumn{4}{|c|}{ Second cut } \\
\hline & \multicolumn{8}{|c|}{2004} \\
\hline Control & 0.030 & 0.019 & 0.012 & 0.020 & 0.033 & 0.036 & 0.017 & 0.028 \\
\hline N1 & 0.051 & 0.044 & 0.026 & 0.040 & 0.062 & 0.087 & 0.035 & 0.062 \\
\hline N2 & 0.044 & 0.041 & 0.024 & 0.036 & 0.068 & 0.090 & 0.067 & 0.075 \\
\hline P1 & 0.047 & 0.025 & 0.014 & 0.029 & 0.048 & 0.054 & 0.049 & 0.050 \\
\hline $\mathbf{P 2}$ & 0.056 & 0.018 & 0.020 & 0.031 & 0.050 & 0.091 & 0.081 & 0.074 \\
\hline Means & 0.045 & 0.030 & 0.019 & & 0.052 & 0.071 & 0.050 & \\
\hline
\end{tabular}

\section{L.S.D. at 0.05 for :}

Irrigation (A)

Bio-fertilizer (B)

0.008

0.008

A x B

0.010

0.010

0.017

0.017

\begin{tabular}{|c|c|c|c|c|c|c|c|c|}
\hline & \multicolumn{8}{|c|}{2005} \\
\hline Control & 0.049 & 0.023 & 0.015 & 0.029 & 0.048 & 0.039 & 0.017 & 0.035 \\
\hline N1 & 0.072 & 0.054 & 0.039 & 0.055 & 0.076 & 0.095 & 0.043 & 0.071 \\
\hline N2 & 0.065 & 0.060 & 0.041 & 0.055 & 0.090 & 0.101 & 0.079 & 0.090 \\
\hline P1 & 0.072 & 0.037 & 0.033 & 0.047 & 0.073 & 0.073 & 0.064 & 0.070 \\
\hline $\mathbf{P 2}$ & 0.079 & 0.033 & 0.038 & 0.050 & 0.072 & 0.115 & 0.077 & 0.088 \\
\hline \multicolumn{2}{|l|}{ Means } & 0.042 & $\mathbf{0 . 0 3 3}$ & & 0.072 & 0.085 & 0.056 & \\
\hline \multicolumn{2}{|c|}{ L.S.D. at 0.05 for : } & & \multicolumn{3}{|c|}{0.013} & & & 0.013 \\
\hline \multicolumn{2}{|c|}{ Irrigation (A) } & & \multicolumn{3}{|c|}{0.017} & & & 0.017 \\
\hline \multicolumn{2}{|c|}{ Bio-fertilizer (B) } & & \multicolumn{3}{|c|}{0.029} & & & 0.029 \\
\hline \multicolumn{2}{|l|}{$A \times B$} & & \multicolumn{3}{|c|}{0.013} & & & 0.013 \\
\hline $\begin{array}{l}\mathrm{N} 1=\text { Nitr } \\
\mathrm{N} 2=\mathrm{Nit}\end{array}$ & $6 \mathrm{~g} /$ & & & ho & $\begin{array}{l}\mathrm{g} / \mathrm{po} \\
\mathrm{g} / \mathrm{po}\end{array}$ & & & \\
\hline
\end{tabular}

Concerning bio-fertilization treatments, both nitrobien and phosphorein at 3 and $6 \mathrm{gm} /$ pot significantly increased oil yield /plant in both two cuts of the two seasons compared with unfertilized control. In the first cut of the first and second seasons, nitrobien at $3 \mathrm{~g} / \operatorname{pot}(\mathrm{N} 1)$ gave the highest oil yield of fresh herb/ plant compared control plants. In the second cut of the first and second seasons, the highest values were obtained from plants fertilized with nitrobien at $6 \mathrm{~g} /$ pot (N2) compared to unfertilized plants. These results agree with those obtained by Mahfoz (2003) on marjoram; Salman (2004) on basil and Heikal (2005) on thyme plants. They showed that bio-fertilization treatments increased essential oil yield. 
Interaction between irrigation intervals and bio-fertilization had a significant effect on oil yield/ plant in both two seasons. In the first cut of the first and second seasons, irrigation every 7 days and bio-fertilization with phosphorein at $6 \mathrm{~g} /$ pot (P2) gave the highest oil yield of fresh herb/ plant compared to irrigation at long intervals and unfertilized control. While in the second cut, in first and second seasons, irrigation interval every 11 days and phosphorein at $6 \mathrm{~g} /$ pot (P2) gave the highest oil yield of fresh herb/plant compared to unfertilized plants which irrigated every 15 days. The increment in the essential oil yield/ plant may be due to the effect of irrigation at short intervals and both nitrobien and phosphorein on increasing both herbage yield and essential oil percentage.

\section{GLC analysis of the essential oil:}

Data on GLC analysis of the essential oil in the first cut of the first season are presented in Table 7 and Figures (1,2 and 3). The data show that, irrigation every 7 days gave the highest linalool and P-cymene percentages in the essential oil, while irrigation every 11 days gave the highest $\alpha$-pinene, $\beta$-pinene, limonene, 1,8 cineol and camphor percentages. Whereas irrigation at long intervals ( every 15 days ) gave the highest $\gamma$ - Terpenene, bornyl acetate, borneol and $\beta$ caryophyllene percentages in the essential oil.

Concerning bio-fertilization treatments, both nitrobien and phosphorein at 3 and $6 \mathrm{~g} /$ pot increased the main constituents of the essential oil ( $\gamma$ - Terpenene, 1,8 cineol, linalool, camphor, P-cymene, bornyl acetate and $\beta$ caryophyllene percentages compared to unfertilized control.

Regarding interaction between irrigation intervals and irrigation intervals, the data show that irrigation every 11 days and nitrobien application at $3 \mathrm{~g} /$ pot gave the highest $\beta$-pinene, 1,8 cineol, camphor and bornyl acetate percentages in the essential oil. Whereas irrigation every 11 days and phosphorein at $3 \mathrm{~g} /$ pot gave the highest linalool and P-cymene percentages in the essential oil.

\section{Total carbohydrates content in herb:}

The total carbohydrates contents in herb as affected by irrigation intervals and bio-fertilization are shown in Table 8. These data indicate that, in the first and second cuts of both first and second seasons, irrigation every 7 days gave the highest total carbohydrates contents in herb compared to the lowest values which obtained from plants irrigated at longer intervals( every 15 days). These results are in agreement with those obtained by; Hammoda (2001) on moghat, they showed that prolonging irrigation intervals decreased total carbohydrates contents.

Concerning bio-fertilization, the data indicate that, in the first cut of the first and second seasons, both nitrobien and phosphorein at 3 and $6 \mathrm{gm} /$ pot increased total carbohydrates contents in herb compared to unfertilized control. Phosphorein application at $6 \mathrm{~g} /$ pot (P2) gave the highest values of total carbohydrates contents in herb. While in the second cut of the first and second seasons, the highest values were obtained from plants fertilized with nitrobien at $6 \mathrm{~g} /$ pot (N2) compared with the lowest values of total carbohydrates content which obtained from unfertilized plants. 
Table 7 : GLC analysis of the essential oil of rosemary ( Rosmarinus officinalis, L.) plants in the first cut of the first season.

\begin{tabular}{|c|c|c|c|c|c|c|c|c|c|c|c|c|}
\hline Trea & tments & 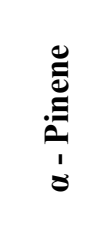 & 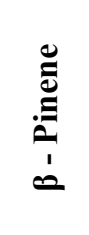 & 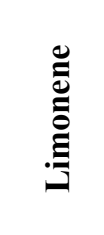 & 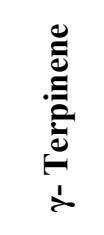 & 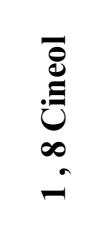 & 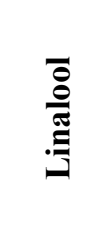 & $\frac{\grave{\Xi}}{\stackrel{\bar{\Xi}}{\bar{E}}}$ & 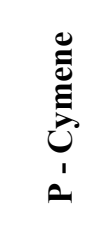 & 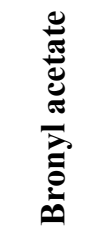 & ف를 & 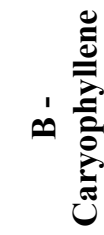 \\
\hline \multirow{5}{*}{$\begin{array}{c}7 \text { - } \\
\text { Days }\end{array}$} & - & 7.63 & 4.25 & 10.95 & 8.20 & 17.45 & 15.61 & 3.47 & 8.53 & 5.29 & 6.78 & 2.03 \\
\hline & N1 & 1.48 & 1.16 & 7.16 & 10.59 & 19.26 & 18.69 & 5.63 & 13.15 & 3.73 & 3.77 & 2.12 \\
\hline & $\mathbf{N} 2$ & 14.34 & 3.91 & 13.06 & 6.55 & 15.14 & 12.68 & 2.71 & 6.12 & 4.33 & 6.04 & 1.99 \\
\hline & P1 & 1.15 & 0.53 & 3.08 & 9.20 & 16.30 & 25.31 & 7.65 & 7.28 & 3.69 & 7.32 & 2.52 \\
\hline & $\mathbf{P 2}$ & 0.69 & 0.48 & 4.96 & 9.96 & 18.07 & 22.90 & 6.84 & 12.69 & 7.69 & 3.17 & 1.91 \\
\hline \multicolumn{2}{|c|}{ Means } & 5.06 & 2.07 & 7.84 & 8.90 & 17.24 & 19.04 & 5.26 & 9.55 & 4.95 & 5.42 & 2.11 \\
\hline \multirow{5}{*}{$\begin{array}{l}11 \text { - } \\
\text { Days }\end{array}$} & -- & 16.90 & 4.45 & 15.72 & 5.36 & 13.99 & 10.67 & 2.11 & 5.09 & 3.39 & 6.46 & 2.06 \\
\hline & N1 & 0.69 & 8.23 & 10.58 & 2.14 & 26.01 & 8.21 & 13.14 & 3.61 & 7.23 & 4.12 & 1.79 \\
\hline & N2 & 7.05 & 4.03 & 9.54 & 8.06 & 15.74 & 15.64 & 3.49 & 7.97 & 5.78 & 7.16 & 2.92 \\
\hline & P1 & 0.60 & 2.89 & 3.95 & 8.89 & 16.83 & 23.71 & 7.33 & 14.35 & 4.68 & 2.74 & 2.46 \\
\hline & P2 & 1.07 & 1.04 & 7.46 & 9.82 & 20.18 & 19.93 & 6.88 & 13.78 & 5.12 & 4.57 & 1.49 \\
\hline \multicolumn{2}{|c|}{ Means } & 5.26 & 4.13 & 9.45 & 6.85 & 18.55 & 15.63 & 6.59 & 8.96 & 5.24 & 5.01 & 2.14 \\
\hline \multirow{5}{*}{$\begin{array}{l}15 \text { - } \\
\text { Days }\end{array}$} & --. & 7.57 & 4.16 & 10.05 & 8.39 & 16.88 & 16.34 & 3.56 & 8.52 & 5.59 & 6.75 & 2.24 \\
\hline & N1 & 3.22 & 3.13 & 8.47 & 9.55 & 17.85 & 18.53 & 4.09 & 8.11 & 7.15 & 6.48 & 3.59 \\
\hline & $\mathbf{N} 2$ & 6.23 & 3.48 & 8.91 & 8.99 & 16.60 & 16.84 & 3.99 & 9.37 & 6.38 & 6.11 & 1.80 \\
\hline & P1 & 6.22 & 3.82 & 9.97 & 8.59 & 16.84 & 16.52 & 3.84 & 8.23 & 5.96 & 6.58 & 2.38 \\
\hline & P2 & 1.65 & 1.48 & 8.87 & 9.59 & 20.98 & 19.35 & 6.54 & 12.03 & 7.27 & 3.50 & 1.40 \\
\hline \multicolumn{2}{|c|}{ Means } & 4.98 & 3.21 & 9.26 & 9.02 & 17.83 & 17.52 & 4.40 & 9.25 & 6.47 & 5.88 & 2.28 \\
\hline \multirow{2}{*}{\multicolumn{2}{|c|}{$\begin{array}{l}\text { Mean of -- } \\
\text { Mean of N1 }\end{array}$}} & 10.70 & 4.29 & 12.24 & 7.32 & 16.11 & 14.21 & 3.05 & 7.38 & 4.76 & 6.66 & 2.11 \\
\hline & & 1.80 & 4.17 & 8.74 & 7.43 & 21.04 & 15.14 & 7.62 & 8.29 & 6.04 & 4.79 & 2.50 \\
\hline \multicolumn{2}{|c|}{ Mean of N2 } & 9.20 & 3.81 & 10.50 & 7.87 & 15.83 & 15.05 & 3.40 & 7.82 & 5.50 & 6.44 & 2.24 \\
\hline \multicolumn{2}{|c|}{ Mean of P1 } & 2.66 & 2.41 & 5.67 & 8.89 & 16.65 & 21.85 & 6.27 & 9.95 & 4.78 & 5.55 & 2.46 \\
\hline \multicolumn{2}{|c|}{ Mean of P2 } & 1.14 & 1.00 & 7.10 & 9.79 & 19.74 & 20.73 & 6.75 & 12.83 & 6.70 & 3.74 & 1.60 \\
\hline
\end{tabular}




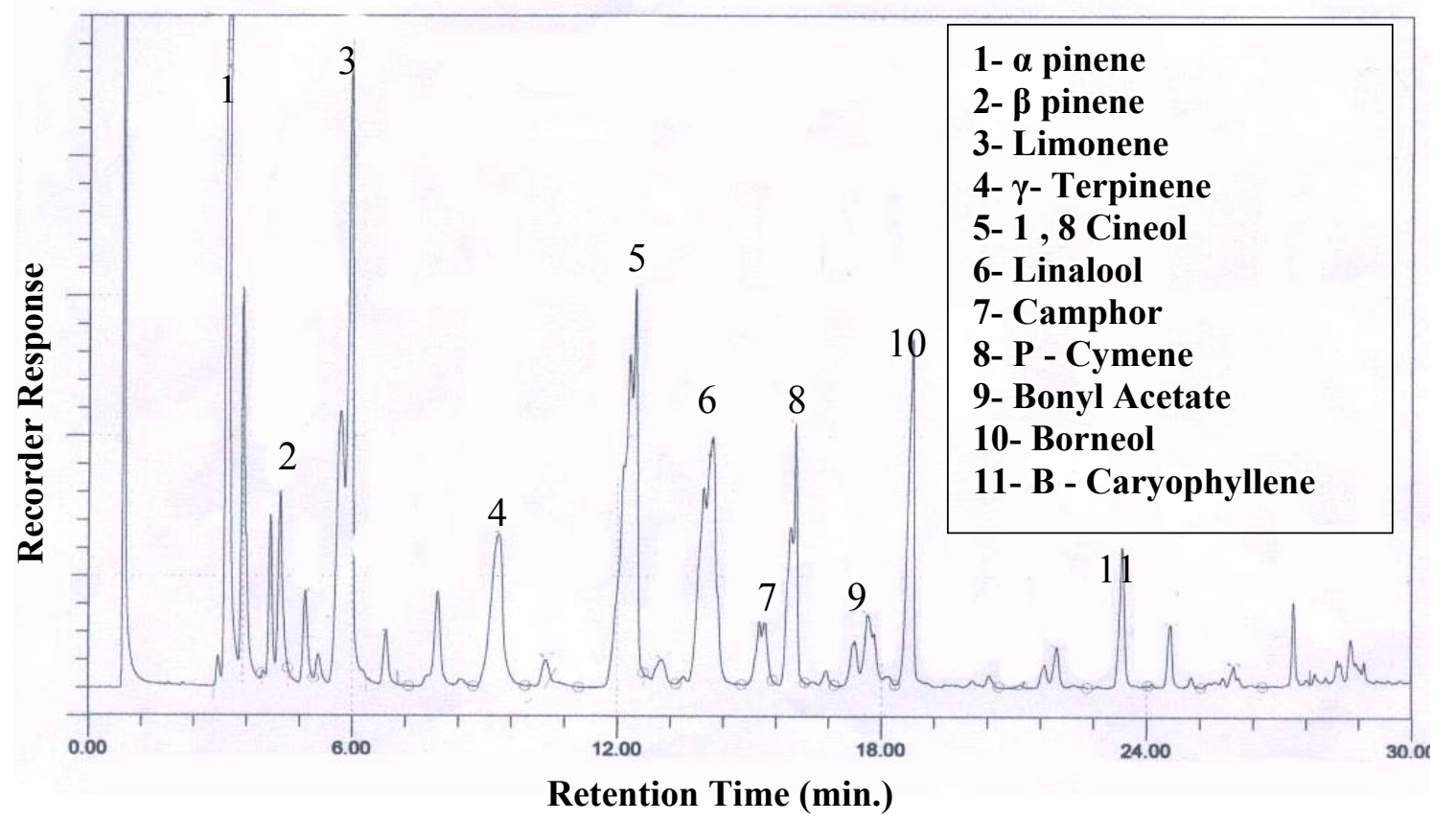

Fig. 1 : Chromatogram of rosemary ( Rosmarinus officinalis, L.) essential oil distilled from control plants irrigated every 11 days in the first cut of the first season.

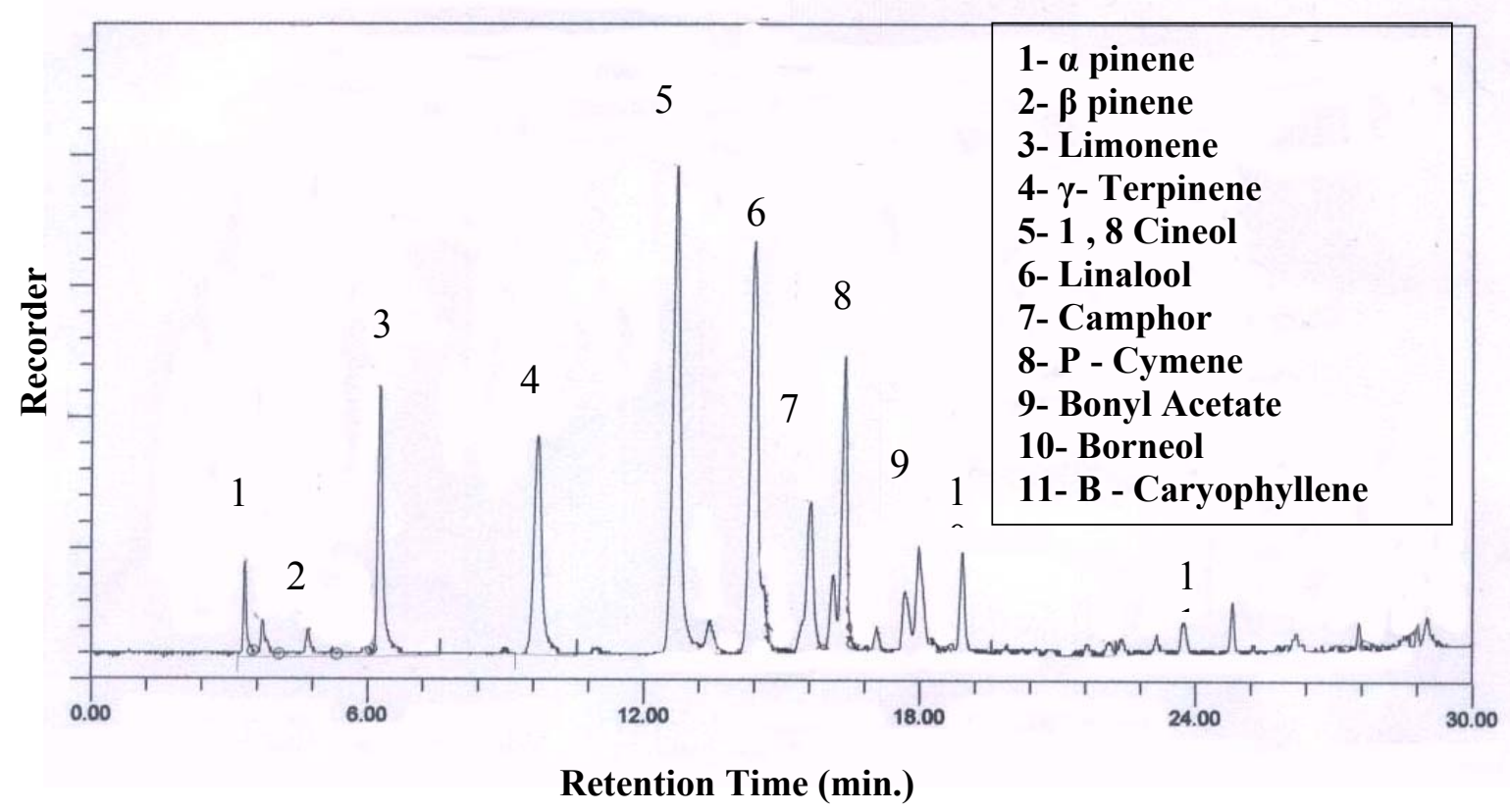

Fig. 2 : Chromatogram of rosemary ( Rosmarinus officinalis, L.) essential oil distilled from plants irrigated every 11 days and treated with nitrobien at $3 \mathrm{gm} / \mathrm{pot}$ in the first cut of the first season. 


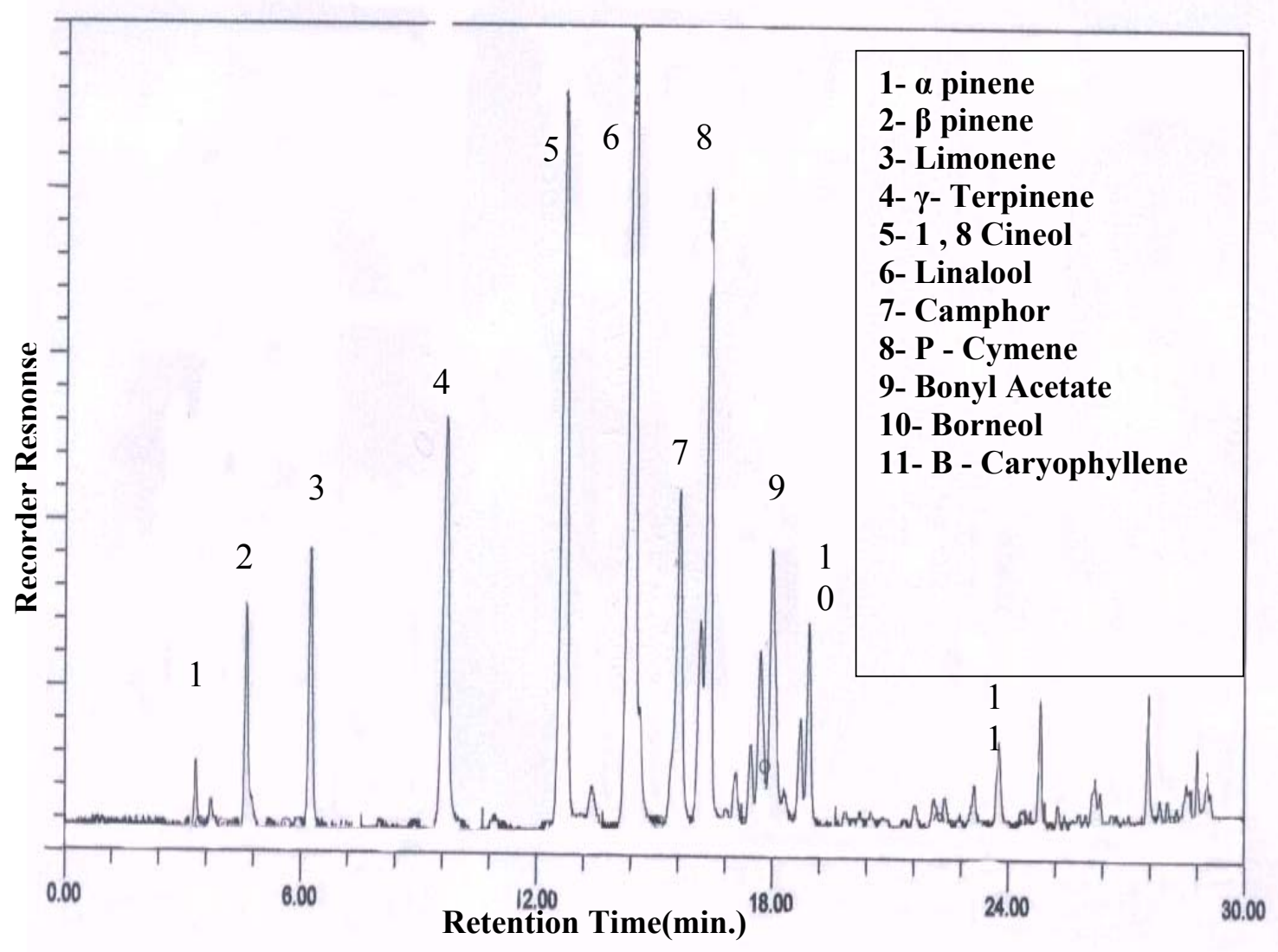

Fig. 3 : Chromatogram of rosemary (Rosmarinus officinalis, L.) essential oil distilled from plants irrigated every 11 days and treated with phosphorein at $3 \mathrm{gm} /$ pot in the first cut of the first season.

The increment in total carbohydrates contents as affected by bio-fertilizers were obtained by Mahfouz (2003) on marjoram; Heikal (2005) on thyme plant, Sakr (2005) on senna plants.

Regarding to interaction between irrigation intervals and bio-fertilization, the data indicate that, in the first and second cuts of the first and second seasons, irrigation every 7 days and bio-fertilization with phosphorein at $6 \mathrm{~g} /$ pot (P2) gave the highest values of total carbohydrates contents in herb compared to irrigation at long interval (every 15 days) which gave the lowest total carbohydrates contents in unfertilized plants. 
Table 8:Effect of irrigation intervals and bio-fertilizers on carbohydrate percentages (\%) of rosemary (Rosmarinus officinalis $L$.) plants during 2004 and 2005 seasons.

\begin{tabular}{|c|c|c|c|c|c|c|c|c|}
\hline Irrigation & 7days & 11days & 15days & Means & 7days & 11days & 15days & Means \\
\hline $\begin{array}{l}\text { Bio- } \\
\text { fertilizers }\end{array}$ & \multicolumn{4}{|c|}{ First cut } & \multicolumn{4}{|c|}{ Second cut } \\
\hline & \multicolumn{8}{|c|}{2004} \\
\hline Control & 7.01 & 6.91 & 6.02 & 6.65 & 6.41 & 6.33 & 6.23 & 6.32 \\
\hline N1 & 7.22 & 7.21 & 7.51 & 7.31 & 6.68 & 6.72 & 6.81 & 6.74 \\
\hline N2 & 7.62 & 7.80 & 7.58 & 7.67 & 7.33 & 7.37 & 7.72 & 7.47 \\
\hline P1 & 6.96 & 6.92 & 6.11 & 6.66 & 6.24 & 6.69 & 6.91 & 6.61 \\
\hline $\mathbf{P 2}$ & 8.29 & 8.18 & 7.06 & 7.84 & 7.87 & 7.25 & 6.64 & 7.25 \\
\hline \multirow[t]{2}{*}{ Means } & 7.42 & 7.40 & 6.86 & ------ & 6.916 & 6.87 & 6.86 & ------ \\
\hline & \multicolumn{8}{|c|}{2005} \\
\hline Control & 6.66 & 6.75 & 5.84 & 6.42 & 6.55 & 6.14 & 6.06 & 6.25 \\
\hline N1 & 6.75 & 7.10 & 7.10 & 6.98 & 6.33 & 6.66 & 6.71 & 6.57 \\
\hline N2 & 7.15 & 7.33 & 7.57 & 7.35 & 6.66 & 6.71 & 6.80 & 6.72 \\
\hline P1 & 6.36 & 6.00 & 6.85 & 6.40 & 6.55 & 6.25 & 6.12 & 6.31 \\
\hline $\mathbf{P 2}$ & 7.90 & 7.50 & 7.00 & 7.47 & 6.76 & 6.33 & 6.30 & 6.46 \\
\hline Means & 6.96 & 6.94 & 6.87 & -ב-- & 6.57 & 6.42 & 6.40 & ---- \\
\hline $\begin{array}{l}\text { N1 }=\text { Nitrobie } \\
\text { N2 = Nitrobi }\end{array}$ & $\begin{array}{l}3 \mathrm{~g} / \mathrm{po} \\
6 \mathrm{~g} / \mathrm{p}\end{array}$ & & $\begin{array}{l}\mathrm{P} 1= \\
\mathrm{P} 2=\end{array}$ & $\begin{array}{l}\text { horein } \\
\text { horeir }\end{array}$ & $\begin{array}{l}\text { g/ pot } \\
\mathrm{g} / \text { pot }\end{array}$ & & & \\
\hline
\end{tabular}

\section{Elements percentage:}

Elements percentage in herb are shown in Tables $(9,10$ and 11). In the first and second cuts of both first and second seasons, irrigation interval every 7 days gave the highest $\mathrm{N}, \mathrm{P}$ and $\mathrm{K}$ percentage in herb compared to irrigation every 15 days which gave the lowest values. Similar results were obtained by Hammoda (2001) on moghat and Alee (2004) on Senna occidentalis, reported that irrigation at short intervals increased N, P and K percentage in herb.

Regarding to bio-fertilization, the data indicate that, both nitrobien and phosphorein at 3 or $6 \mathrm{~g}$ /pot increased $\mathrm{N}, \mathrm{P}$ and $\mathrm{K}$ percentage in herb compared to control in the first and second cuts of the first and second seasons. Phosphorein at 6 or $3 \mathrm{~g} /$ pot (P2) gave the highest $\mathrm{N}$ and $\mathrm{P}$ percentage in herb, respectively. Nirobien application at $6 \mathrm{~g} /$ pot (N2) gave the highest $\mathrm{K}$ percentage in herb. whereas the lowest $\mathrm{N}, \mathrm{P}$ and $\mathrm{K}$ percentage in herb were obtained from unfertilized plants. Migahed et. al., (2004)on celery; Zayed et. al., (2004) on borage; Heikal (2005) on thyme plant and Sakr (2005) on senna plants. 
Table(9):Effect of irrigation intervals and biofertilizers on nitrogen percentages ( \%) in herb of rosemary(Rosmarinus officinalis L.)plants during 2004 and 2005 seasons.

\begin{tabular}{|c|c|c|c|c|c|c|c|c|}
\hline Irrigation & 7 days & 11days & 15days & Means & 7 days & 11days & 15 days & Means \\
\hline $\begin{array}{c}\text { Bio- } \\
\text { fertilizers }\end{array}$ & \multicolumn{4}{|c|}{ First cut } & \multicolumn{4}{|c|}{ Second cut } \\
\hline \multicolumn{9}{|c|}{2004} \\
\hline Control & 1.69 & 1.57 & 1.00 & 1.42 & 1.88 & 1.65 & 1.22 & 1.58 \\
\hline N1 & 2.08 & 1.86 & 1.49 & 1.81 & 2.25 & 1.77 & 1.39 & 1.80 \\
\hline N2 & 2.26 & 2.21 & 1.74 & 2.07 & 2.44 & 1.91 & 1.62 & 1.99 \\
\hline P1 & 2.69 & 2.17 & 1.29 & 2.05 & 2.71 & 1.83 & 1.48 & 2.01 \\
\hline $\mathbf{P 2}$ & 2.96 & 2.18 & 2.15 & 2.43 & 2.89 & 2.01 & 1.93 & 2.28 \\
\hline Means & 2.34 & 2.00 & 1.53 & --- & 2.43 & 1.83 & 1.53 & --- \\
\hline \multicolumn{9}{|c|}{2005} \\
\hline Control & 1.51 & 1.48 & 1.25 & 1.41 & 1.49 & 1.35 & 1.31 & 1.38 \\
\hline N1 & 1.83 & 1.77 & 1.52 & 1.71 & 1.75 & 1.71 & 1.40 & 1.62 \\
\hline $\mathbf{N 2}$ & 1.96 & 1.91 & 1.80 & 1.89 & 1.88 & 1.75 & 1.69 & 1.77 \\
\hline P1 & 2.10 & 2.05 & 2.00 & 2.05 & 1.95 & 1.84 & 1.73 & 1.84 \\
\hline $\mathbf{P 2}$ & 2.22 & 2.19 & 2.11 & 2.17 & 2.00 & 1.92 & 1.81 & 1.91 \\
\hline \multirow[t]{2}{*}{ Means } & 1.92 & 1.88 & 1.74 & ---- & 1.81 & 1.71 & 1.59 & --- \\
\hline & $\begin{array}{l}\mathrm{N} 1=1 \\
\mathrm{~N} 2=\end{array}$ & $\begin{array}{l}\text { bien at } \\
\text { bien at }\end{array}$ & $\begin{array}{l}\text { pot } \\
/ \text { pot }\end{array}$ & & $\begin{array}{l}\text { Phos } \\
\text { Phos }\end{array}$ & $\begin{array}{l}1 \text { at } 3 g \\
1 \text { at } 6 g\end{array}$ & & \\
\hline
\end{tabular}

Concerning interaction between irrigation intervals and bio-fertilization, the data indicate that, in the first and second cuts of the first and second seasons, irrigation every 7 days and bio-fertilization with phosphorein at $6 \mathrm{~g} /$ pot (P2) gave the highest $\mathrm{N}$ percentage in herb, while_ irrigation every 7 days and bio-fertilization with phosphorein at $3 \mathrm{~g} /$ pot $(\mathrm{P} 1)$ gave the highest values of $\mathrm{P}$ percentage in herb. Whereas irrigation interval every 7 days and bio-fertilization with nitrobien application at $6 \mathrm{~g} /$ pot (N2) gave the highest $\mathrm{K}$ percentage in herb compared to unfertilized control and irrigation at long intervals ( every 15 days) which gave the lowest $\mathrm{N}, \mathrm{P}$ and $\mathrm{K}$ percentage in herb.

\section{REFERENCES}

Aly, S. H. S. M. (2004): Effect of irrigation intervals and salt concentration on growth and chemical composition of (Senna occidentalis, L.) M. Sc. Thesis, Fac. Agric., Cairo Univ. Egypt.

British Pharmacopoeia (1963): The Pharmaceutical Press 17 Bloomsbury. Square London, W.C.L. 
Table10: Effect of irrigation intervals and bio-fertilizers on phosphorus percentages (\%) in herb of rosemary (Rosmarinus officinalis L.) plants during 2004 and 2005 seasons.

\begin{tabular}{|c|c|c|c|c|c|c|c|c|}
\hline $\begin{array}{l}\text { Irrigation } \\
\text { Intervals }\end{array}$ & 7days & 11days & 15days & Mean & 7days & 11days & 15days & Means \\
\hline $\begin{array}{c}\text { Bio- } \\
\text { fertilizers }\end{array}$ & \multicolumn{4}{|c|}{ First cut } & \multicolumn{4}{|c|}{ Second cut } \\
\hline \multicolumn{9}{|c|}{2004} \\
\hline Control & 0.16 & 0.15 & 0.12 & 0.14 & 0.18 & 0.16 & 0.12 & 0.15 \\
\hline N1 & 0.29 & 0.18 & 0.18 & 0.22 & 0.30 & 0.20 & 0.17 & 0.22 \\
\hline N2 & 0.19 & 0.14 & 0.13 & 0.15 & 0.20 & 0.14 & 0.13 & 0.16 \\
\hline P1 & 0.35 & 0.24 & 0.15 & 0.25 & 0.36 & 0.32 & 0.16 & 0.28 \\
\hline $\mathbf{P 2}$ & 0.29 & 0.22 & 0.15 & 0.22 & 0.21 & 0.22 & 0.18 & 0.20 \\
\hline Means & 0.26 & 0.19 & 0.15 & ----- & 0.25 & 0.21 & 0.15 & ---- \\
\hline \multicolumn{9}{|c|}{2005} \\
\hline Control & 0.13 & 0.13 & 0.12 & 0.13 & 0.12 & 0.11 & 0.10 & 0.11 \\
\hline N1 & 0.19 & 0.17 & 0.16 & 0.17 & 0.16 & 0.15 & 0.15 & 0.15 \\
\hline N2 & 0.17 & 0.15 & 0.14 & 0.15 & 0.14 & 0.13 & 0.12 & 0.13 \\
\hline P1 & 0.22 & 0.20 & 0.16 & 0.19 & 0.18 & 0.16 & 0.15 & 0.16 \\
\hline P2 & 0.20 & 0.19 & 0.17 & 0.19 & 0.16 & 0.14 & 0.14 & 0.15 \\
\hline Means & 0.18 & 0.17 & 0.15 & ---- & 0.15 & 0.14 & 0.13 & $\overline{----}$ \\
\hline \multicolumn{5}{|c|}{$\begin{array}{l}\mathrm{N} 1=\text { Nitrobien at } 3 \mathrm{~g} / \text { pot } \\
\mathrm{N} 2=\text { Nitrobien at } 6 \mathrm{~g} / \text { pot }\end{array}$} & \multicolumn{3}{|c|}{$\begin{array}{l}1=\text { Phosphorein at } 3 \mathrm{~g} / \mathrm{pot} \\
2=\text { Phosphorein at } 6 \mathrm{~g} / \text { pot }\end{array}$} & \\
\hline
\end{tabular}

Bunzen,J. ; N. Guichard ; J. Labbe ; P. Prevot ; J. Sperpinet and J. Trenchant (1969): Practical Manual of Gas Chromatography. El- Seiver Publ.Com., Amsterdam, London.

Hammam, K. A. (2002): Effect of irrigation intervals and chemical fertilization on growth, yield and chemical constituents of Cassia acutifolia plants. Ph.D. Thesis, Fac. Agric., Cairo Univ. Egypt.

Hammoda, S. S. M. (2001): Effect of some agricultural treatments on growth and productivity of moghat plant under Sinai conditions. M. Sc. Thesis, Fac. Agric., Cairo Univ. Egypt.

Heikal, A., A. M. (2005): Effect of organic and bio-fertilization on growth, production and composition of thyme (Thumus vulgaris, L.) plant. M. Sc. Thesis, Fac. Agric., Cairo Univ. Egypt.

King, E. J. (1951): Microanalysis in Medical Biochemistry. $2^{\text {nd }}$ Ed. Churchill. London, UK.

Kock, F. G. and T. L. McMeeking (1924): A new direct nesslerization microkejldahl method and amodification of the Nessler-folin reagent from ammonia. J. Amer. Chem. Soc., 46:2066. 
Lawless, J. (1992):The Encyclopedia of Essential Oils. Element Books Limited, Longmead, Shaftsbury, Dorset, London, USA, Element, Inc.42 Broadway. Rockport, MA 01966, 78-79.

Mahfoz, S. A. (2003): Effect of bio-fertilization on growth and oil production of marjoram (Marjorana hortensis, Moench). Ph. D. Thesis, Fac. Agric., Cairo Univ. Egypt.

Migahed, H. A.; A. E. Ahmed and B. F. Abd El-Ghany (2004): Effect of different bacterial strains as bio-fertilizeres agents on growth, production and oil of Apium graveolens under calcareous soil. Arab Univ. J. of Agric. Sci.; 12(2): 511-525.

Sakr, W. R. A. (2005): Effect of organic and bio-fertilization on growth and constituents production senna plants. M. Sc. Thesis, Fac. Agric., Cairo Univ. Egypt.

Salman, A. S. (2004). Effect of bio-fertilization on Ocimum basilicum, L. plant M. Sc. Thesis, Fac. Agric., Cairo Univ. Egypt.

Shalan, M. N.(2005): Effect of compost and different sources of biofertilizeres, on borage plants (Borago officinalis, L.). Egypt J. of Agric. Res., 83(1): 271284.

Shalan, M. N.; T. A. Abd El-Latif; S. G. I. Soliman and E. O. El-Gawwas (2001): Effect of some chemical and bio-fertilizers treatments on Roselle plants "Hibiscus sabdariffa, L." Egypt J. Agric. Res., 79(2):587- 606.

Singh, M. (2004): Effects of plant spacing, fertilizer, modified urea material and irrigation regime on herbage, oil yield and oil quality of rosemary in semiarid tropical conditions. J. of Horti. Sci. and Biotechn., 79(3): 411-415.

Snedecor, G. W. and W. G. Cochran (1980): Statistical Methods. $6^{\text {th }}$ Ed., The Iowa State Univ., Press, Iowa, U.S.A.

Toima, N. M.; H.A. Bosila; A. K. Youssef and I. S. Amin (1984): Effect of soil type and irrigation intervals on the growth, fruit yield, volatile oil percentage and carbohydrate contents in Carum carvi, L. (caraway). desert inst. Bull., A. R. E., 34(1-2): 133-144.

Yassen, M.; P. Ram; Anju-Yadav and K. Singh (2003): Response of Indian basil (Ocimum basilicum) to irrigation and nitrogen schedule in Central Uttar Pradesh. Annals of Plant Physiology, 17(2): 177-181.

Youssef, A. A.; A. E. Edris and A. M. Gomaa (2004): A comparative study between some plant growth regulators and certain growth hormones producing microorganisms on growth and essential oil composition of Salvia officinalis, L. plants. Annals of Agric. Sci. Cairo., 49(1): 299-311.

Zayed, A. A.; S. M. Sleim; M. A. Hassanain and Y. A. M. Hafez (2004): Effect of sowing spacings, nitrogenous and bio-fertilization treatments on yield and chemical composition of borage plants (Borago officinalis, L.). Egypt J. of Agric. Res., 82 (2) (Special Issue)): 187-206. 


\section{تأثير فترات الري والتسميد الحيوي علي النمو والمحصول وإنتاج الزيت والتركيب الكيماوي لنباتات حصالبان}

\section{احمد الليثى}

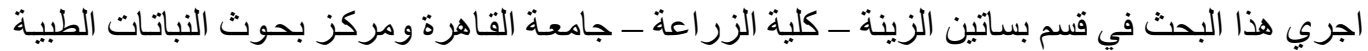

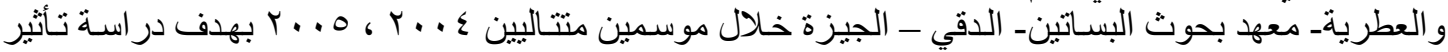

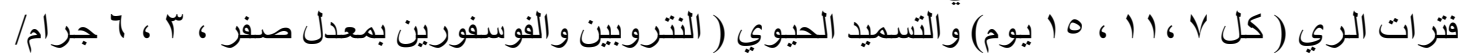

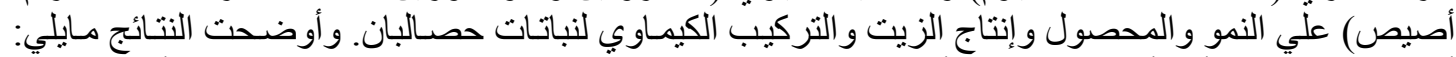

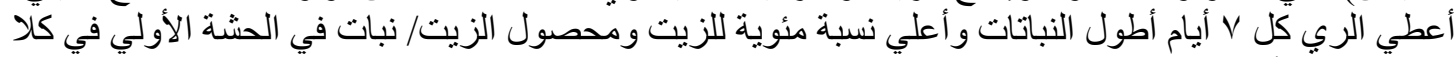

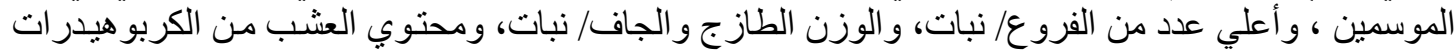

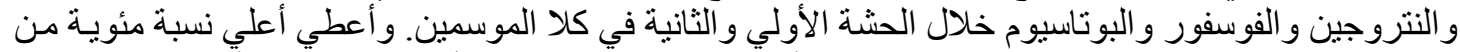

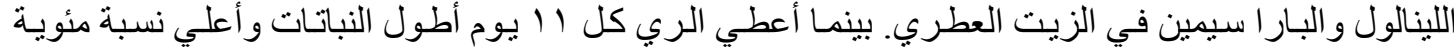

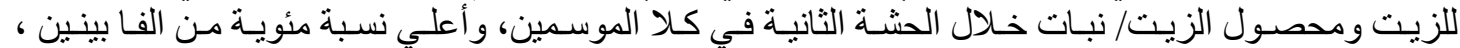

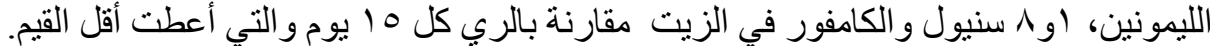

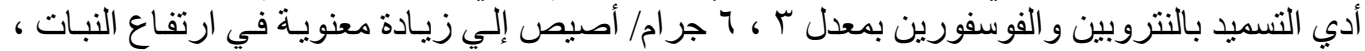

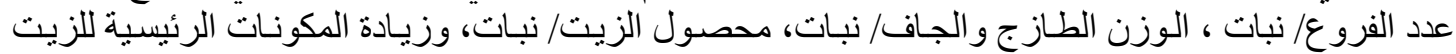

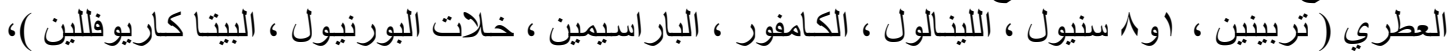

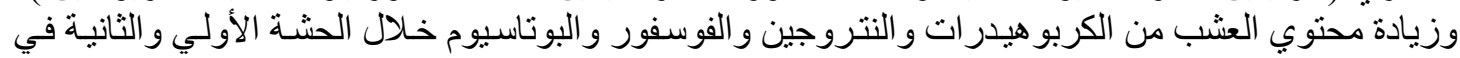

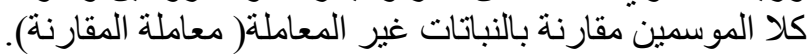

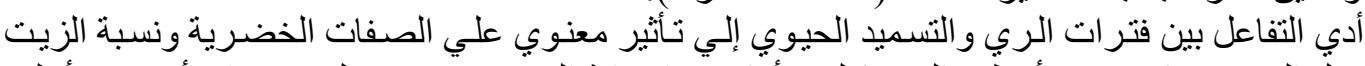

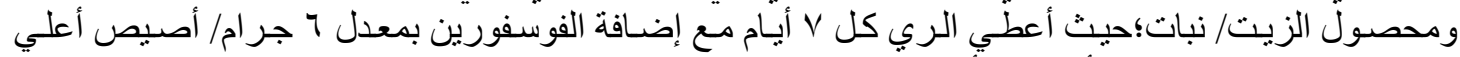

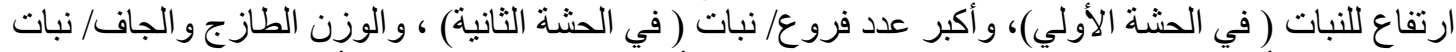

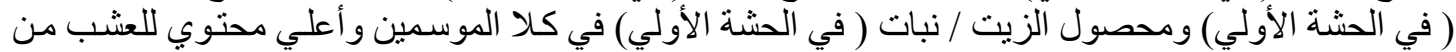

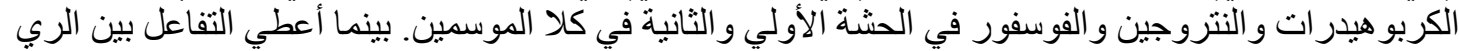

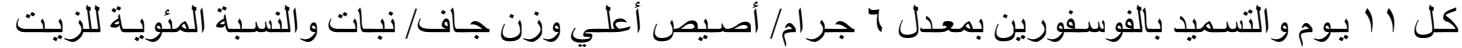

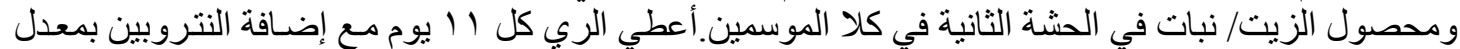

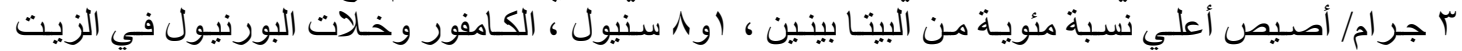

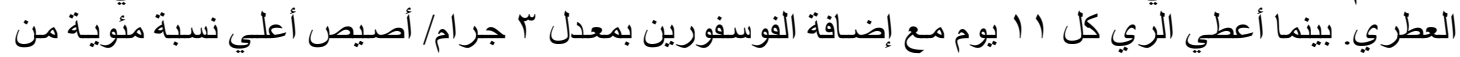
اللينالول و البار ا سيمين في الزيت الريت العطري. 